\title{
A new uppermost Albian flora from Teruel province, northeastern Spain
}

\author{
Luis Miguel SENDER \\ Universidad de Zaragoza, Departamento Ciencias de la Tierra (Paleontología), \\ c/ Pedro Cerbuna 12, E-50009 Zaragoza (Spain) \\ Imsender@unizar.es \\ Uxue VILLANUEVA-AMADOZ \\ Instituto de Geología, UNAM, Departamento de Paleontología, \\ Ciudad Universitaria, Coyoacan 04510 México D.F. (Mexico) \\ Uxuevillanueva@yahoo.es \\ Jose Bienvenido DIEZ \\ Raquel SANCHEZ-PELLICER \\ Universidad de Vigo, \\ Departamento Geociencias Marinas y Ordenación del Territorio, \\ Campus Lagoas-Marcosende, E-36200 Vigo, Pontevedra (Spain) \\ jbdiez@uvigo.es \\ sanchezpellicer@uvigo.es \\ Antoine BERCOVICI \\ Lund University, Department of Geology, \\ Sölvegatan 12, SE-223 62 Lund (Sweden) \\ antoine.bercovici@geol.lu.se \\ Denise PONS \\ Université Pierre et Marie Curie, UMR 7207, \\ Muséum national d'Histoire naturelle, \\ Centre de Recherche en Paléobiodiversité et Paléoenvironnements \\ case postale 48, 57 rue Cuvier, F-75231 Paris cedex 05 (France) \\ denise.pons@snv.jussieu.fr \\ Javier FERRER \\ Universidad de Zaragoza, Departamento Ciencias de la Tierra (Paleontología), \\ c/ Pedro Cerbuna, 12, E-50009 Zaragoza (Spain) \\ joferrer@unizar.es
}

Sender L. M., Villanueva-Amadoz U., Diez J. B., Sanchez-Pellicer R., Bercovici A., Pons D. \& Ferrer J. 2012. - A new uppermost Albian flora from Teruel province, northeastern Spain. Geodiversitas 34 (2): 373-397. http://dx.doi.org/10.5252/g2012n2a7 
KEY WORDS

Palaeobotany, palynology, angiosperms,

Utrillas Formation, Late Albian, Spain.

\begin{abstract}
This paper reports a new Early Cretaceous flora discovered recently near the village of Estercuel (Teruel province, northeastern Spain). The plant bearing beds belong to the uppermost part of the Early Cretaceous succession, at the top of the fluvial deposits of the Utrillas Formation. The site has yielded a diverse assemblage of plant compressions including lycopods and ferns, various gymnosperms as well as terrestrial and aquatic angiosperms. Leaves of aquatic lycopods (Isoetites sp.) constitute a minor component of the palaeobotanical assemblage. Filicales are not very common, with Dicksoniales (Onychiopsis sp.) and a few specimens of Cladophlebis type fronds. The gymnosperms are represented by fragmented remains of long parallel veined Desmiophyllum leaves as well as a great abundance of conifer axis corresponding to the form-genus Pagiophyllum and female cones. Terrestrial angiosperms include pinnately lobed leaves of the genus Myricompia, simple leaves with spatulate lamina and some petiolate leaves both corresponding to angiosperms of uncertain affinity. Aquatic angiosperms consist of Nelumbo-like floral receptacles (Nelumbonaceae, Proteales) and Aquatifolia cf. fuitans (Nympheales). The palynological assemblage is dominated by pollen of gymnosperms (mainly Taxodiaceaepollenites hiatus, Classopollis major and Araucariacites australis). It also includes many angiosperm grains (Afropollis jardinus, Clavatipollenites spp., Dichastopollenites spp., Liliacidites doylei, Monosulcites chaloneri, Penetetrapites mollis, Pennipollis spp., Phimopollenites augathellaensis, Retimonocolpites textus, Rousea spp., Senectotetradites varireticulatus, Stellatopollis barghoornii, Striatopollis spp., Transitoripollis sp. cf. T. similis, Tricolpites spp., Tricolporoidites sp.) and records the first occurrence of tricolporate forms in the uppermost part of the Utrillas Formation. Both macroflora and microflora assemblages present taxa similar to those of the uppermost Albian Shaftesbury Formation in northwestern Alberta in Canada, the uppermost Albian Denton Shale Member of Bokchito Formation in southern Oklahoma, the lower part of the Upper Albian Dakota Formation from the mid-west of North America, and Subzone II C of the Potomac Group, eastern United States. Both macro- and microflora assemblages display boreal influence with some similar taxa to those of the Upper Albian Kome Formation in western Greenland and some taxa as Afropollis jardinus and Stellatopollis barghoornii more frequently found in the tethyan and gondwanan realms. A gondwanan affinity is also indicated by the presence of Klitzschophyllites leaves.
\end{abstract}

\section{RÉSUMÉ}

Une nouvelle flore de l'Albien supérieur terminal de la province de Teruel, nord-est de l'Espagne.

Ce travail met l'accent sur la découverte d'une nouvelle flore d'âge crétacé inférieur près du village d'Estercuel (province de Teruel, nord-est de l'Espagne). Les niveaux fossiliferes, situés au sommet des dépôts fluviaux de la formation Utrillas, sont surmontés par les grès marins peu profonds de la formation Mosqueruela. Le site a livré des assemblages diversifiés de plantes en compression incluant des lycopodes et des fougères, des gymnospermes variées ainsi que des angiospermes terrestres et aquatiques. Les feuilles de lycopodes aquatiques (Isoetites sp.) constituent un composant mineur de l'assemblage floristique. Les filicales sont peu communes, avec des dicksoniales (Onychiopsis sp.) et quelques spécimens de type Cladophlebis. Les gymnospermes sont représentées par de longues feuilles fragmentaires à nervures parallèles (Desmiophyllum), par une grande abondance d'axes de coniferes correspondant au morphogenre Pagiophyllum, ainsi que par des cônes 
MOTS CLÉS

Paléobotanique, palynologie, angiospermes,

formation Utrillas,

Albien supérieur

terminal,

Espagne. femelles. Les angiospermes terrestres incluent des feuilles pennées lobées (Myricompia), des feuilles spatulées et quelques feuilles pétiolées d'affinités incertaines. Les Angiospermes aquatiques consistent en réceptacles floraux semblables à ceux de Nelumbo (Nelumbonaceae, protéales) et de Aquatifolia cf. fuitans (nymphéales). La palynoflore est dominée par des grains de pollen de gymnospermes (principalement Taxodiaceaepollenites hiatus, Classopollis major et Araucariacites australis). Sont également inclus de nombreux grains d'angiospermes comprenant Afropollis jardinus, Clavatipollenites spp., Dichastopollenites spp., Liliacidites doylei, Monosulcites chaloneri, Penetetrapites mollis, Pennipollis spp., Phimopollenites augathellaensis, Retimonocolpites textus, Rousea spp., Senectotetradites varireticulatus, Stellatopollis barghoornii, Striatopollis spp., Transitoripollis sp. cf. T. similis, Tricolpites spp. et Tricolporoidites sp. Les deux assemblages (macro- et palynoflores) sont similaires à ceux de l'Albien terminal de la formation Shaftesbury du NE de l'Alberta (Canada), de l'Albien terminal du membre Denton Shale de la formation Bokchito au sud de l'Oklahoma (USA), de la partie inférieure de l'Albien supérieur de la formation Dakota du centre-ouest de l'Amérique du Nord et de la sous-zone II C du groupe Potomac (est des USA). Les deux assemblages présentent des influences à la fois boréales et gondwaniennes, avec quelques taxons comparables à ceux de l'Albien supérieur de la formation Kome à l'ouest du Groenland. La présence de feuilles du genre Klitzschophyllites montre des affinités gondwaniennes.

\section{INTRODUCTION}

The Albian-Cenomanian transition represents a keyperiod in the diversification of eudicot angiosperms. During this period of time, the fossil records show a major change in the systematic composition of angiosperms assemblages with a marked increase in abundance and complexity of angiosperm leaves (Hickey \& Doyle 1977; Lidgard \& Crane 1988; Vakhrameev 1991; Upchurch \& Wolfe 1993; Friis et al. 2010). Associated with the changes in the angiosperm macrofossil assemblages, there is also a change in the palynological assemblage worldwide with an increase in tricolpate and other triaperturate pollen in the Late Cretaceous (Singh 1975; Doyle \& Robbins 1977; Hickey \& Doyle 1977; Wingate 1980; Villanueva-Amadoz et al. 2011).

Several rich macrofossil floras corresponding to the Albian-Cenomanian transition have been described from western Europe (Gomez et al. 2004), central Asia (Vakhrameev 1952, 1976, 1991; Samylina 1988) and also in the North-American mid-west Dakota Formation (Lesquereux 1883, 1892; Berry
1922; Rushforth 1971; Hickey \& Doyle 1977; Upchurch \& Dilcher 1990; Schwarzwalder \& Dilcher 1991; Skog \& Dilcher 1992, 1994; Skog et al. 1992; Wang 2002, 2008; Wang \& Dilcher 2006a, b). More recently, Gomez et al. (2009) and Sender et al. (2010) described fossil leaves from the Albian-Cenomanian of Spain focusing exclusively on the aquatic elements, because of their relatively rare occurrence. The plant fossils described in this paper are important in documenting higher diversity of different groups of plants than previously known in the Albian-Cenomanian deposits of Spain.

\section{GEOLOGICAL SETTING AND STRATIGRAPHY}

The site is located in the west of the Aragonese Branch of the Iberian Chain, near the village of Estercuel (Teruel province, northeastern Spain) (Fig. 1), in the Oliete subbasin (Soria 1997). The plant bearing beds belong to the uppermost part of the Early Cretaceous succession at the top of 


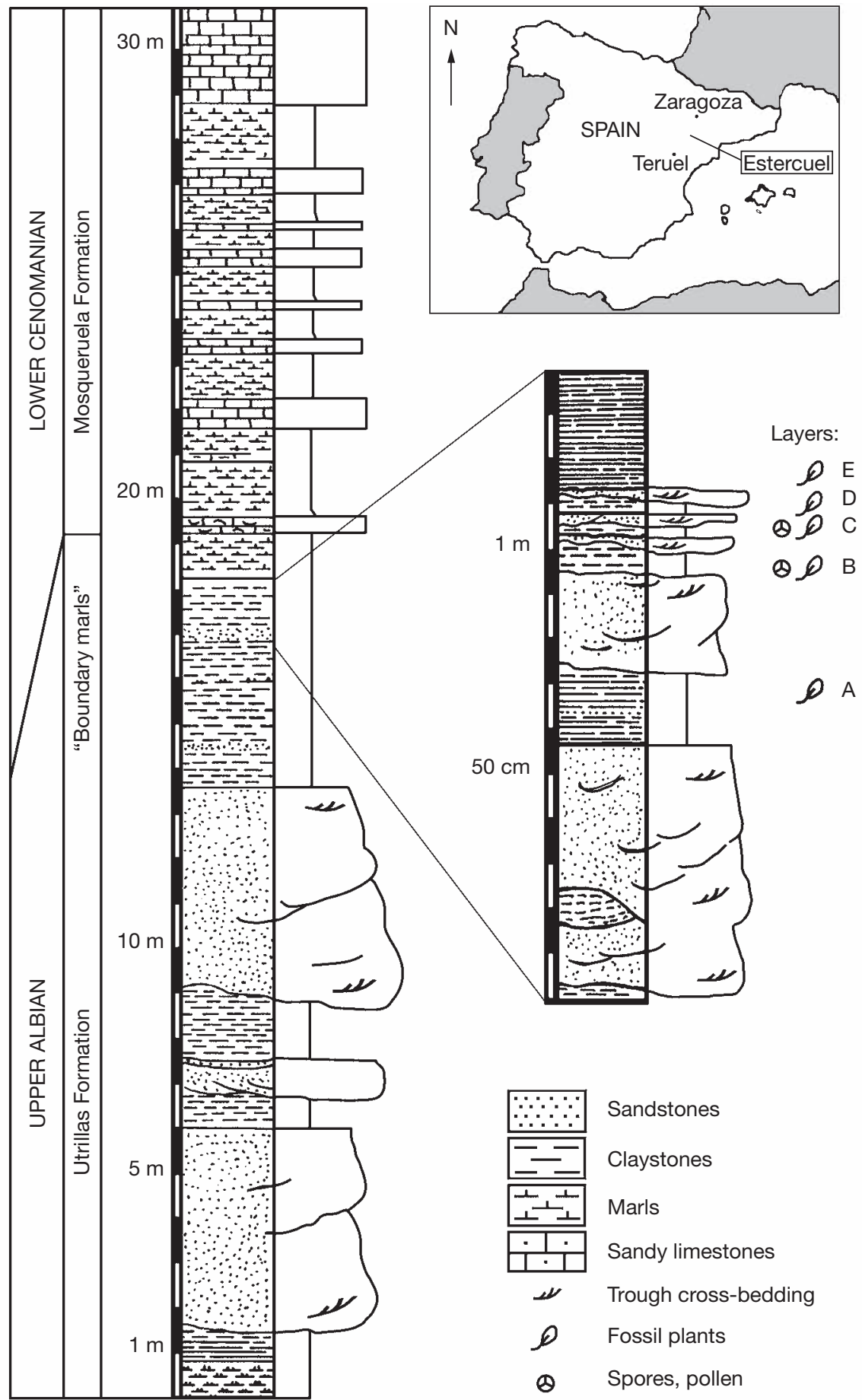

FIG. 1. - Location and stratigraphic section of the fossil site of Estercuel (Teruel province, northeastern Spain) and position of the fossil plants levels within the Boundary Marls Unit (modified from Pardo 1979). 


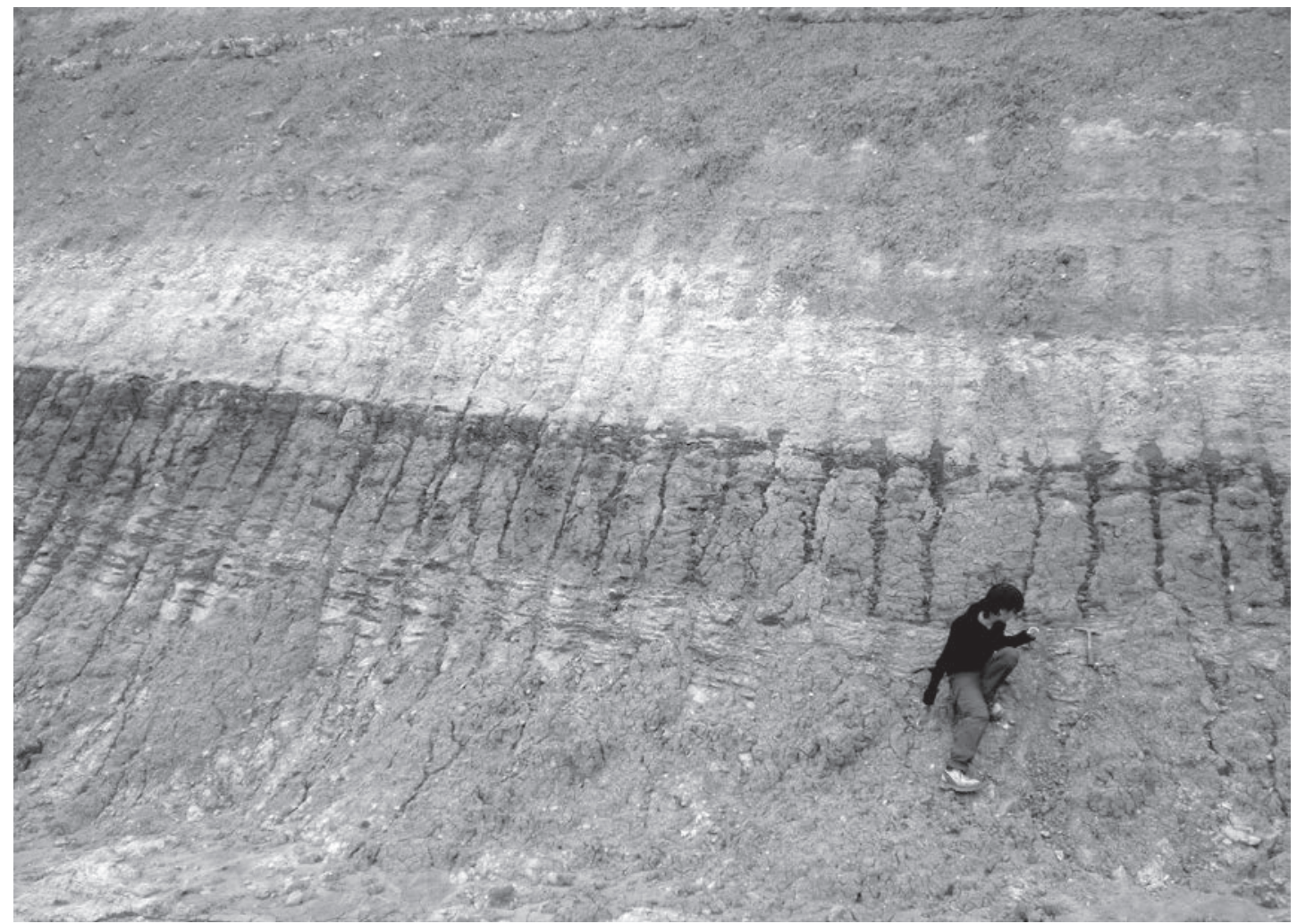

FIG. 2. - General view of the outcrop in the Estercuel quarry (Teruel province, northeastern Spain).

the fluvial deposits of the Utrillas Formation. The Utrillas Formation is composed of sandstone bodies with intercalations of coloured silty claystones with increasing occurrence upward. The upper part represents a finning upward sequence of grey to dark coloured marls constituting the "Boundary Marls" unit (named as "Margas de Transición" unit by Aguilar et al. 1971). The "Boundary Marls" contains the flora studied here and represents the transitional layers between the fluvial deposits of the Utrillas Formation and the overlying shallow marine deposits of the Mosqueruela Formation (Fig. 1). The fossil plants and palynological assemblages were collected from five layers indicated in the stratigraphic log (Fig. 1[A-E]).

The age of the "Boundary Marls" unit was previously established as latest Albian and the underlying Utrillas Formation as middle-latest
Late Albian on the basis of the palynological assemblage in other localities of the same basin (Villanueva-Amadoz 2009). Moreover, the overlying Mosqueruela Formation has been dated in several sections nearby the Estercuel site on the basis of the assemblage of benthic foraminifera: Cenomanian in Huesa del Común and Puerto de Rudilla localities (Lendínez et al. 1989), Lower Cenomanian in the Puerto de San Just (Neumann \& Schroeder 1985; Calonge 1989) and Upper Albian next to Fortanete village (Canérot 1974).

Two different floral assemblages preserved in different lithologies and different stratigraphic levels can be distinguished: the basal stratigraphic level is composed of grey claystones intercalated with fine to coarse grained yellow sandstones, which were deposited in a tidally influenced 
fluvial sedimentary environment (Fig. 2). This level contains both abundant and diverse and exceptionally well-preserved macrofloral and microfloral assemblages.

The upper stratigraphic level consists of dark grey to black laminated claystones deposited in a swampy environment with lower diversity of floral elements (Fig. 2).

\section{MATERIAL AND METHODS}

The samples were collected during fieldwork associated to programs 223/2008 and 081/2009 of the Diputación General de Aragón (Government of Aragón, Spain).

The plant macrofossils are preserved mainly as compressions, and some specimens have a thin coaly surface. The plant macrofossils were prepared under a stereomicroscope by removing the matrix with a percussion hammer and mounted needles.

A total of 267 plant macrofossils were studied. They are for the moment housed in the Museo Paleontológico of Universidad de Zaragoza (Spain) with the denominations MPZ 2010/910 to MPZ 2010/1175 and MPZ 2009/342.

Five samples were processed for palynological study using standard technique (Erdtman 1943): $20 \mathrm{~g}$ of each sample were crushed in a mortar, carbonates were dissolved with $10 \% \mathrm{HCl}$ and the silicates removed with $70 \% \mathrm{HF}$ and $10 \% \mathrm{HCl}$; later, the organic residue was oxidized with $30 \% \mathrm{HNO}_{3}$, then washed three times with water and centrifuged. The residue was filtered through a $100 \mu \mathrm{m}$ mesh sieve, but in order to keep the smallest angiosperm pollen grains $(<10 \mu \mathrm{m})$, no other sieving operation was undertaken. The residue was permanently mounted for observation in Loctite 350.

The slides were analyzed at the Muséum national d'Histoire naturelle (Paris). A total of 143 individual palynomorphs were photographed. Several separate optical section images were taken for each palynomorph and depth of field was reconstructed using the free image stacking program CombineZM (Hadley 2006; Bercovici et al. 2009). Scanning electron micrographs were taken at Vigo University using a Phillips XL 30 SEM.

\section{SYSTEMATIC PALAEOBOTANY}

Division LYCOPHYTA Scott, 1909

Class LYCOPSIDA Scott, 1909

Order ISOETALES Prantl, 1874

Family IsOETACEAE Reichenb., 1828

Genus Isoetites Munster, 1842

Isoetites sp.

Layers B to D (Fig. 4B, D)

SPECIMENS. - MPZ 2010/910 to MPZ 2010/926.

\section{DESCRIPTION}

Leaves simple, elongated to lanceolate, up to $4 \mathrm{~cm}$ long and $5 \mathrm{~mm}$ wide. Margin entire, base slightly expanded and apex acute. Leaves preserved as longitudinal sections showing a gross mid vein up to $2 \mathrm{~mm}$ wide. Leaves are lacunate, with trabeculae inter-distance measuring $1 \mathrm{~mm}$. Only a single specimen shows preserved fertile parts, bearing an enlarged sporangial region at the base and containing clumps of microspores. For an accurate description and detailed palynological analysis of this particular specimen see Villanueva-Amadoz et al. 2012.

\section{Division PTERIDOPHYTA Schimper, 1879 Class POLYPODIOPSIDA Cronquist, Takht. \& Zimmerm., 1966 \\ Order CYATHEALES A. B. Frank, 1877}

Family DickSONIACEAE M. R. Schomb., 1848 Genus Onychiopsis Yokoyama, 1889

\section{Onychiopsis sp.}

Layers A to D (Fig. 4C)

SPECIMENS. - MPZ 2010/927 to MPZ 2010/935.

\section{DESCRIPTION}

Fragments of bipinnate fronds. Secondary pinna subtriangular up to $6.3 \mathrm{~cm}$ long and $2 \mathrm{~cm}$ wide. Pinnules alternate, lanceolate, highly lobed. Lobules lanceolate to triangular acute which are best developed at the base of pinnules. Venation consists of several thin veins which enter the pinnule from the base forking several times to end in the margins. 


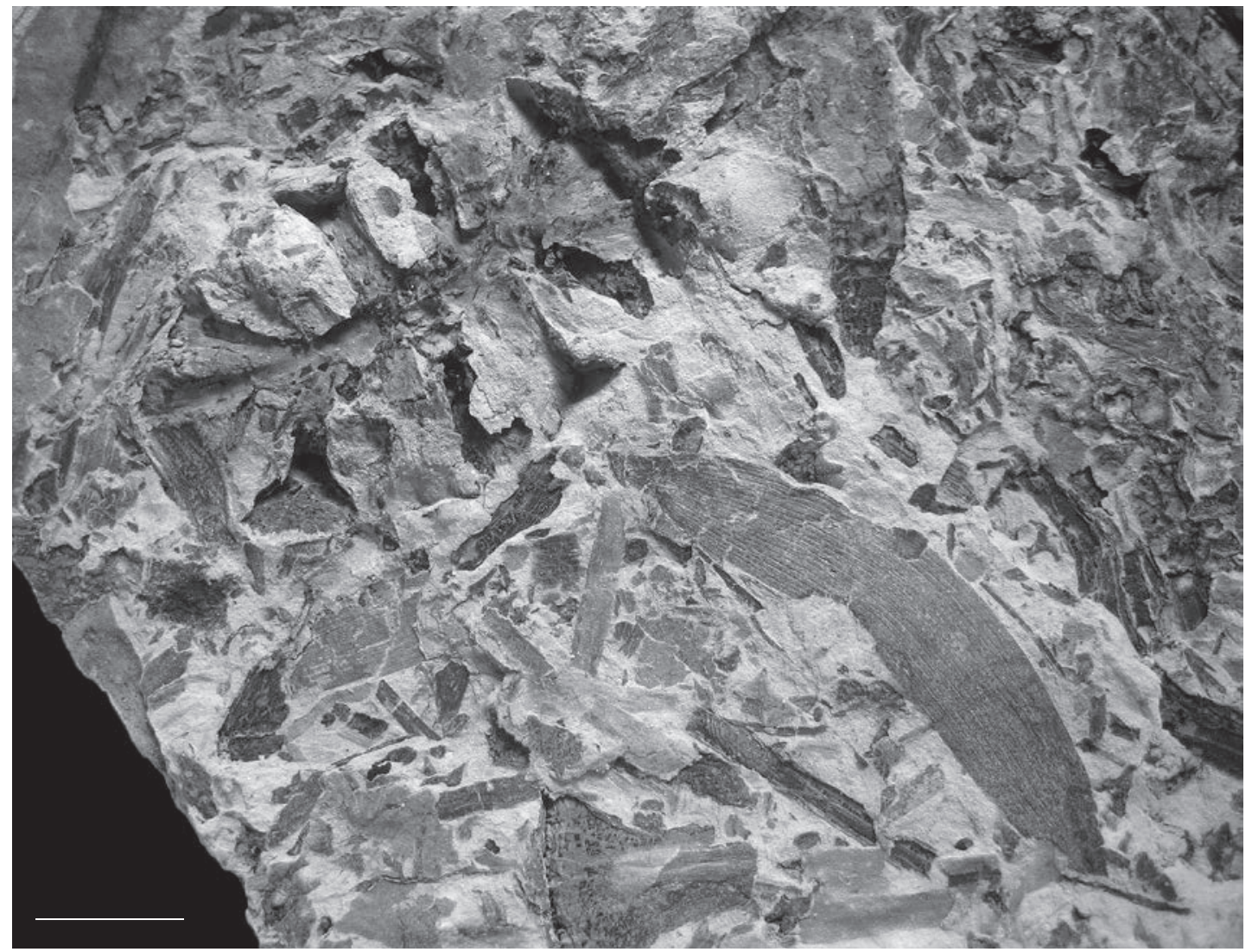

FIG. 3. - Concentration of fossil plant remains (conifer female cone and scales fragments, one Podozamites (Brongniart) Braun, 1843 leaf and fragments of angiosperm leaves type 1) and comminuted plant debris on a slab from the lowermost fossiliferous level. Scale bar: $1 \mathrm{~cm}$.

Family indet.

Form-genus Cladophlebis Brongniart, 1849

Cladophlebis sp.

Layer E (Fig. 4A)

SPECIMEN. - MPZ 2010/936.

DESCRIPTION

Fragments of penultimate pinnae up to $4.5 \mathrm{~cm}$ long and $2.5 \mathrm{~cm}$ wide bearing ultimate pinnae alternate and lanceolate, slightly decurrent at base. Pinnules opposite to sub-opposite, ovoidal. Margin of pinnules entire, joined to the rachis by the entire base. Apex rounded. Venation is difficult to distinguish, but apparently comprises one medial vein with diverging alternate secondary veins which fork up to the margins.
Division PINOPHYTA

Cronquist, Takht. \& Zimmerm., 1996 Class PINOPSIDA Burnett, 1835

Family indet.

Form-genus Pagiophyllum Heer, 1881

\section{Pagiophyllum sp.}

Layers A to E (Fig. 5D, F)

SPECIMENS. - MPZ 2010/937 to MPZ 2010/1024.

\section{DESCRIPTION}

Fragments of twigs up to $12 \mathrm{~cm}$ long, branched up to three times and bearing spirally arranged scale-like leaves (up to $4 \mathrm{~mm}$ long and $1.5 \mathrm{~mm}$ wide). Leaves are rhombic, slightly decurrent at the base, appressed proximally and separated from the axis just in the 


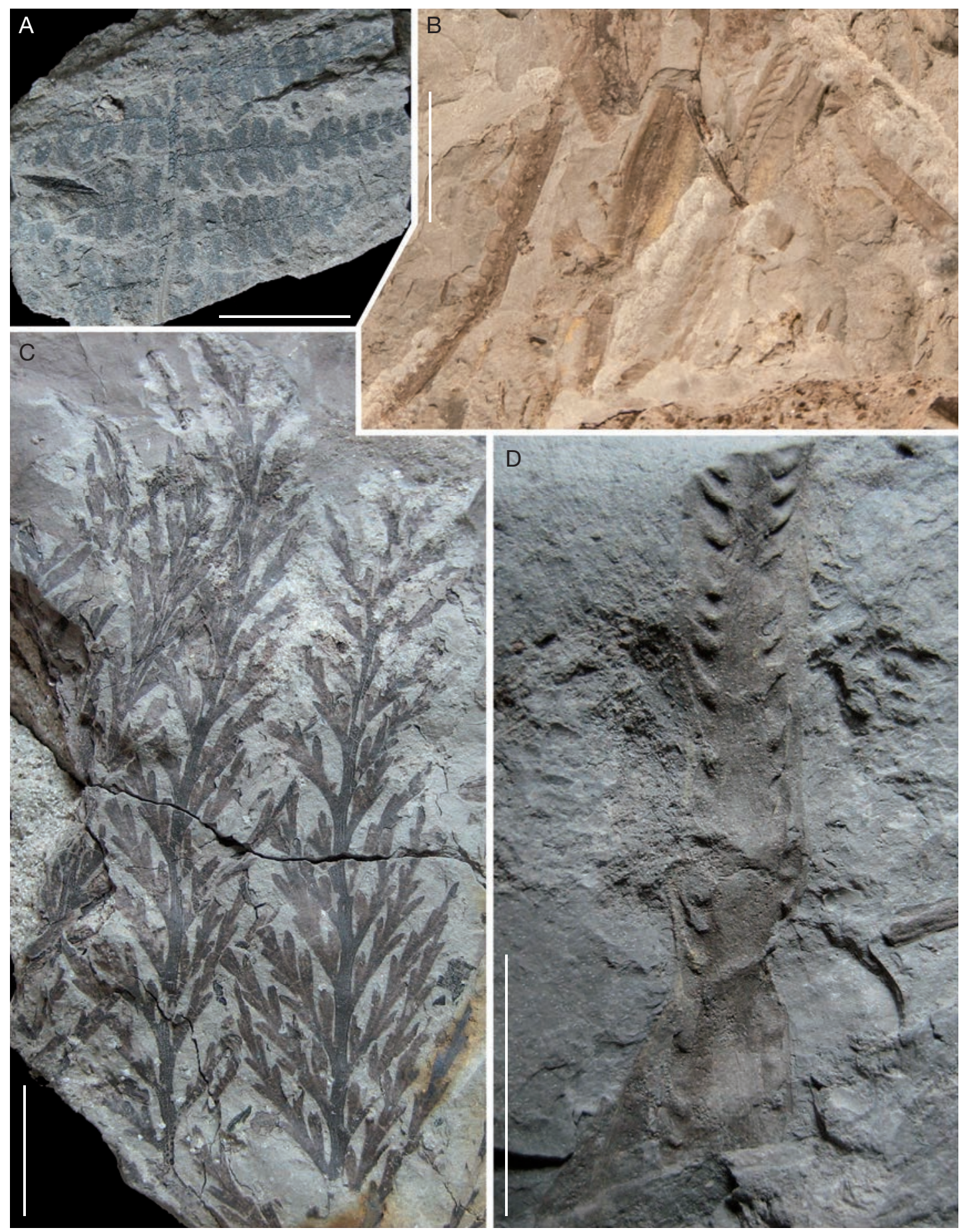

FIG. 4. - Lycopsids and ferns: A, fern Cladophlebis sp., fragment of secondary pinna; B, accumulation of /soetites leaves (Lycopsida); C, fern Onychiopsis sp., secondary pinnae; D, Isoetites sp., isolated leaf showing trabeculae. Scale bars: $1 \mathrm{~cm}$. 

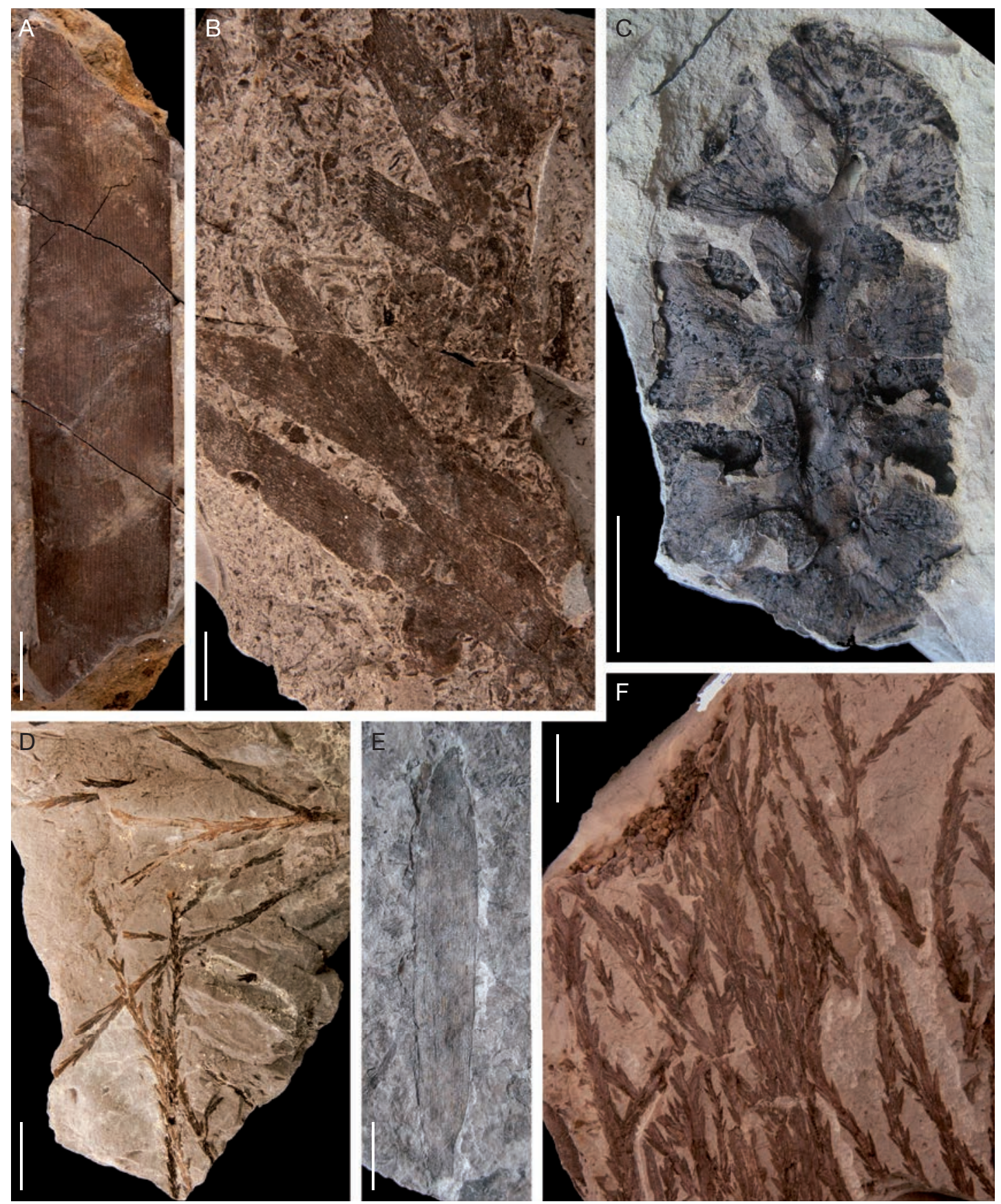

FIG. 5. - Gymnosperms of the Estercuel plant fossil site (Teruel province, northeastern Spain): A, Desmiophyllum sp.; B, fragments of Podozamites (Brongniart) Braun, 1843 leaves; C, conifer seed cones; D, Pagiophyllum sp., branched shoots; E, Podozamites sp.; F, Pagiophyllum sp. shoots. Scale bars: $1 \mathrm{~cm}$. 
first $1 / 3$ of their length. A medial keel is present on the abaxial face of the leaves and a medial groove present on the adaxial face. Apex of leaves sharply acute.

Family indet.

Form-genus Podozamites (Brongniart) Braun, 1843

Podozamites sp.

Layers A to E (Fig. 5 B, E)

SPECIMENS. - MPZ 2010/1025 to MPZ 2010/1034.

\section{DESCRIPTION}

Leaves lanceolate up to $7 \mathrm{~cm}$ long and $1 \mathrm{~cm}$ wide. Lamina tapers at the base into a narrow wing. Apex rounded to obtusely pointed. Venation composed of numerous parallel veins (c. 30 veins per $\mathrm{cm}$ ) equally spaced, which diverge from a point at base and fusing apparently at apex.

\section{Conifer seed cones}

Layer B (Fig. 5 C)

SPECIMENS. — MPZ 2010/1035 to MPZ 2010/1039.

\section{DESCRIPTION}

Cones seen in longitudinal sections up to $4.5 \mathrm{~cm}$ long and $2.5 \mathrm{~cm}$ wide. Scales robust and woody, spirally arranged, semicircular to trapezoidal in section up to $1 \mathrm{~cm}$ long and $7.5 \mathrm{~mm}$ wide. Surface of scales shows numerous thin veins running parallel from the base up to the apex.

Family indet.

Form-genus Desmiophyllum Lesquereux, 1878 Layers A to E (Fig. 5 A)

SPECIMENS. - MPZ 2010/1040 to MPZ 2010/1052.

\section{DESCRIPTION}

Fragments of elongate strap-like leaves up to $12 \mathrm{~cm}$ long and $2 \mathrm{~cm}$ wide. Margins straight and reinforced. Base and apex not preserved. Venation consists of numerous gross veins, c. 25 veins per $\mathrm{cm}$, running parallel to leaf margins. Another four thin veins extended between two gross veins making a total of $c .125$ veins per $\mathrm{cm}$.

\section{REMARKS}

Similar leaves were also found in the Aptian-Albian of western Europe (Coiffard et al. 2007), Canada (Bell 1956) and in Albian-Cenomanian deposits of Alaska (Spicer \& Herman 2001) and Russia (Spicer et al. 2002).

Class ANGIOSPERMAE Lindley, 1830 Order NYMPHAEALES

Salisb. ex Bercht. \& J. Presl, 1820

Family cf. NympHAEACEAE Salisb., 1805

Genus Aquatifolia Wang \& Dilcher, 2006

\section{Aquatifolia cf. fluitans}

Layers B to D (Fig. 6B, C)

SPECIMENS. - MPZ 2010/1130 to MPZ 2010/1134 and MPZ 2009/342.

\section{DESCRIPTION}

Leaf orbicular to ovate, petiolate. Base cordate. Base angle wide obtuse. Petiole stout with an expanded fusiform float in its lower part. Float length is $60 \mathrm{~mm}$ long and $17 \mathrm{~mm}$ wide in its central part. Leaf blade up to $39 \mathrm{~mm}$ long and $45 \mathrm{~mm}$ wide (no complete specimens). Margin crenate with tooth type convexconvex. Primary venation basal actinodromous with one medial vein branching up to the margin and four lateral primary veins which fork several times, gradually decreasing in thickness toward the margin. Angle between primary veins $45^{\circ}$. Branches from primary veins join to form polygonal large meshes. Secondary venation apparently craspedodromous. Tertiary and quaternary veins forming small polygonal meshes.

\section{REMARKS}

The unique combination of spherical to fusiform floats and foliar lamina with Nymphaeaceae-like venation together with other characteristics is charateristic for the genus Aquatifolia Wang \& Dilcher from the Hoisington III locality, Kansas, USA (Wang \& Dilcher 2006a). The Spanish fossils are closely similar to the 

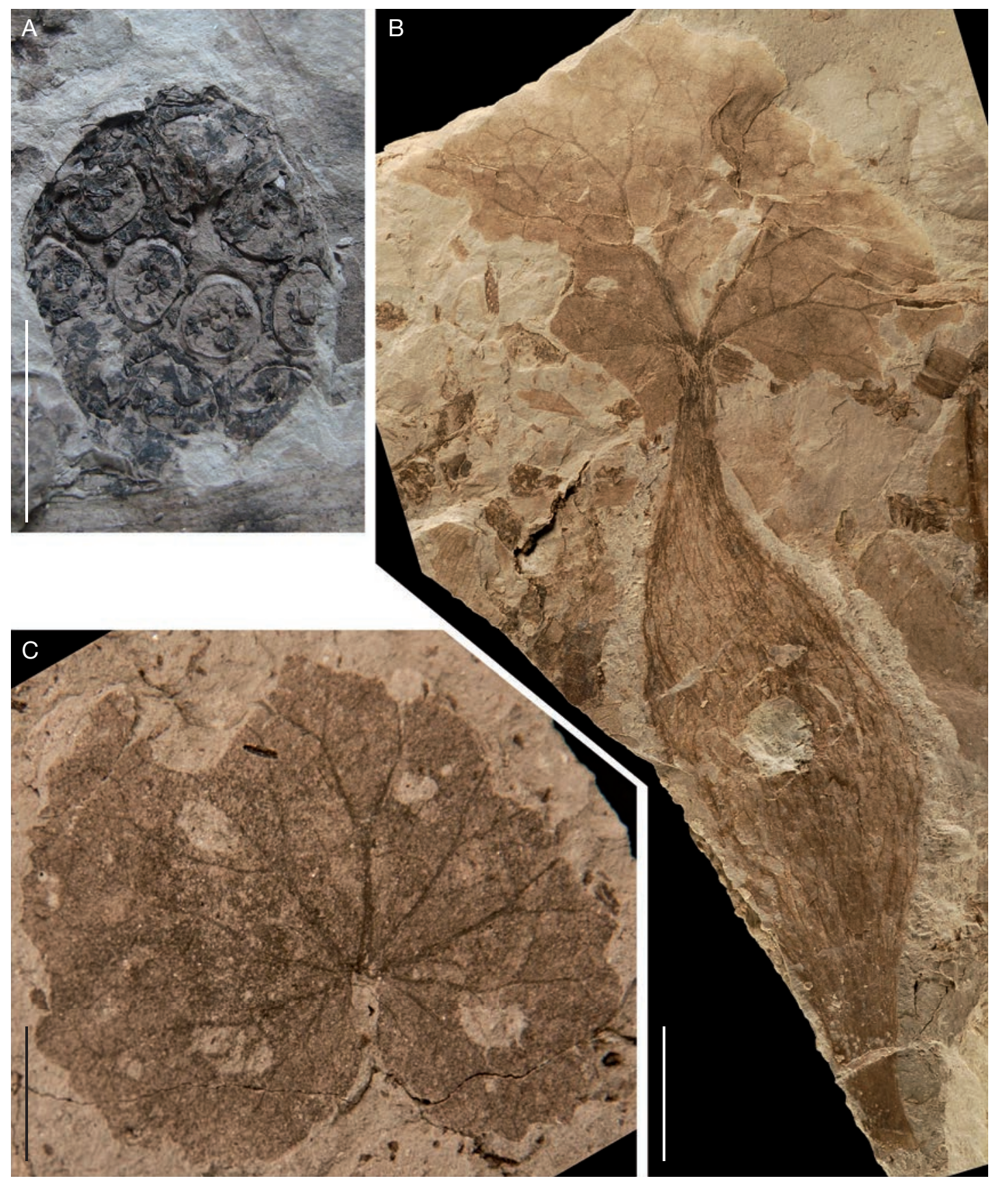

FIG. 6. - Fertile and sterile structures of aquatic plants: A, floral receptacles of presumable Nelumbonaceae floral receptacle showing internal moulds of achene cavities; B, Aquatifolia cf. fluitans, aquatic plant with foliar lamina, petiole and fusiform float organ at base; C, almost complete lamina of Aquatifolia cf. fluitans showing venation. Scale bars: $1 \mathrm{~cm}$. 
type species Aquatifolia fluitans (Wang \& Dilcher 2006a), but because leaf margin and endings of veins are not well preserved, we hesitate to include the spanish material in the same species. Currently the genus has only been recovered from the Estercuel outcrop and the Hoisington III locality.

\section{Order PROTEALES}

Juss. ex Bercht. \& J. Presl, 1820

Family NelumbonaceAe A. Rich., 1827

Layer B (Fig. 6A)

REPRODUCTIVE STRUCTURES. - Floral receptacles.

SPECIMENS. - MPZ 2010/1135 and MPZ 2010/1136.

\section{DESCRIPTION}

Structures circular in outline, about $3.5 \mathrm{~cm}$ in diameter, containing up to 10 smaller, protuberant and circular units, about $0.45 \mathrm{~cm}$ in diameter. The smaller units are surrounded by a circular ridge and groove. The apex of each unit possesses a central sunken pit with several grooves radiating from the center.

\section{REMARKS}

The characters of the fossil suggest that they are floral receptacles with moulds of cavities containing achenes, probably related to the Nelumbonaceae. They closely resemble fossils from the Upper Albian Potomac Group in the Quantico locality (Virginia, USA), described by Upchurch et al. (1994) as Nelumbites.

They are also similar to the Nelumbo-like structures from the Campanian-Maastrichtian La Colonia Formation from Patagonia, Argentina (Gandolfo \& Cúneo 2005) and to the receptacles of extant $\mathrm{Ne}$ lumbo Nelumbonaceae (Proteales) (Hayes et al. 2000; Miller et al. 2009).

Other angiosperms of uncertain placement Incertae sedis

Angiosperm type 1

Layers A to E (Figs 7A-E; 8A)

SPECIMENS. — MPZ 2010/1137 to MPZ 2010/1172.

\section{DESCRIPTION}

Leaves simple, up to $25 \mathrm{~cm}$ long and $5 \mathrm{~cm}$ wide, elliptical to spatulate in shape with marked decurrent lamina at base. Margin entire and reinforced. Base probably rounded but not totally preserved. Apex rounded or slightly emarginate in some specimens. Mid-vein strong. Secondary veins semicraspedodromus, alternate, very dense at base. Vein spacing decreasing toward base with secondary veins very closely spaced at the basal lamina tissue. Vein angle increasing toward base with veins disposed at right angles in the base of lamina and at acute angles from the medial part up to the apex. Intersecondaries weak, two to four. Tertiary veins alternate percurrent. Quaternary veins alternate percurrent to polygonal reticulate. Quinternary veins regular polygonal reticulate. Areoles well developed.

\section{REMARKS}

The leaves resemble some extent that of Jaramillophyllum celatus (Lesquereux) Wang (nomen nudum) in size and spatulate-shaped lamina, reinforced margin, strong by decurrent lamina and craspedodromus secondary venation described from the Dakota Formation of the Hoisington III locality in Kansas (USA), Late Albian in age (Wang 2002).

\section{Angiosperm type 2 Layers A to C \\ (Fig. 8B)}

SPECIMENS. - MPZ 2010/1173 to MPZ 2010/1175.

\section{DESCRIPTION}

Fragments of leaves up to $7 \mathrm{~cm}$ long and $3 \mathrm{~cm}$ wide, simple, elliptical to lanceolate in shape. Margin entire. Base cuneate. Apex not preserved. Petiole straight and narrow $(1.5 \mathrm{~cm}$ long and $2 \mathrm{~mm}$ wide). Mid-vein stout and strong. Secondary veins craspedodromus to weak brochidodromous disposed at acute angles from primary vein. Intersecondaries weak. Tertiary veins alternate percurrent. Quaternary veins apparently alternate percurrent. 

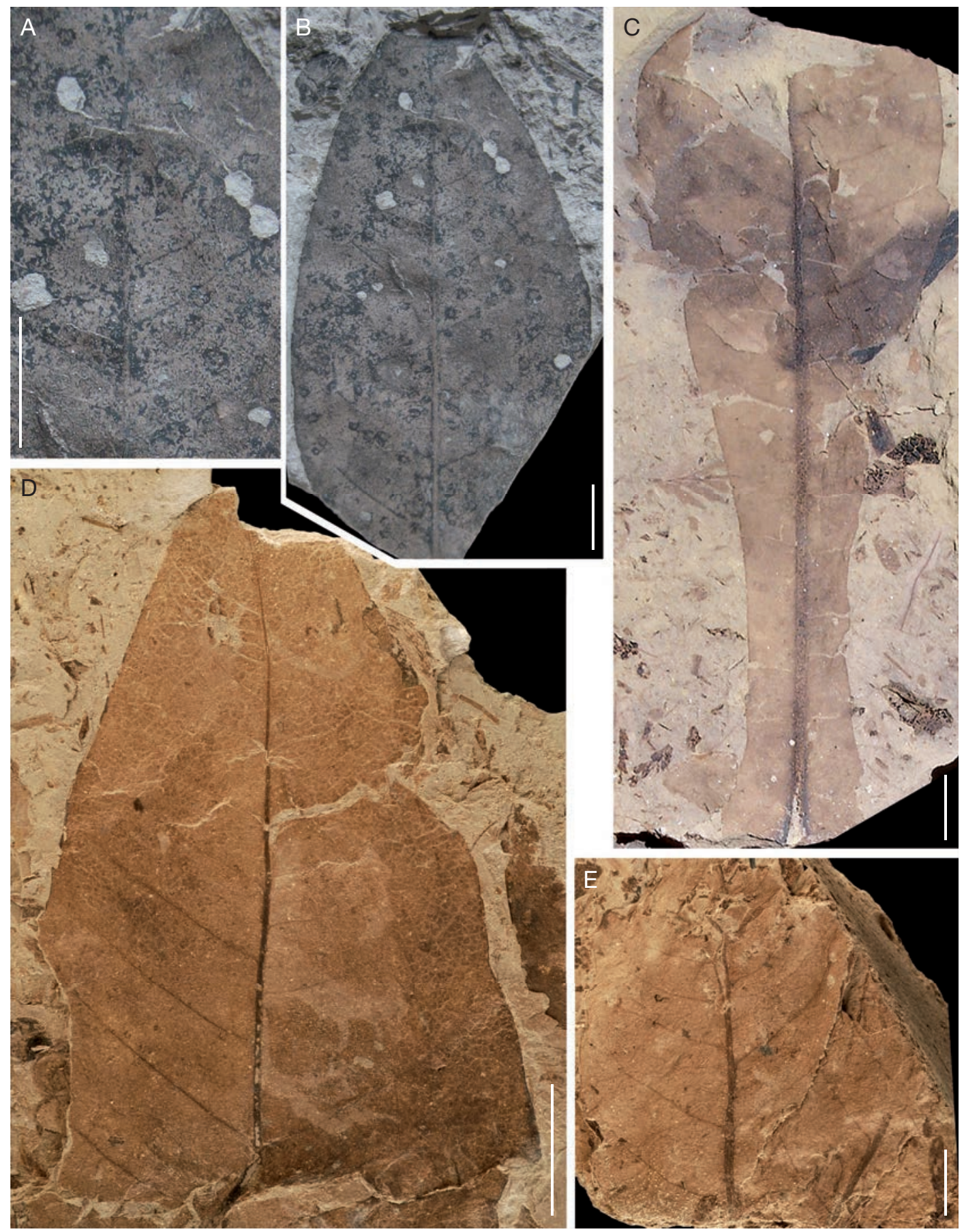

FIG. 7. - Angiosperms type 1 leaf morphology and venation pattern: A, detail of insect feeding holes in the surface of a leaf; B, complete leaf apical fragment showing feeding holes and fungi black marks; C, nearly complete leaf with characteristic spatulate morphology; D, detail of venation pattern in the apical part of an angiosperm type 1; E, detail of venation pattern in the central part of a leaf. Scale bars: $1 \mathrm{~cm}$. 
Genus Myricompia Boyd, 1998

\author{
Myricompia sp. \\ Layers A and B \\ (Fig. 9C)
}

SPECIMENS. - MPZ 2010/1053 to MPZ 2010/1056.

\section{DESCRIPTION}

Fragments of pinnately lobed leaves up to $4 \mathrm{~cm}$ long and $1 \mathrm{~cm}$ wide. Lobes are short and pointed, with entire margin and acute apex. They are connected by a narrow lamina parallel to the primary vein. Primary vein straight and narrow. Numerous secondary veins are disposed at acute angles from the base of lobes. Two secondary veins enter into each lobe and fork almost twice before ending freely at the margins.

\section{REMARKS}

This genus was erected by Boyd (1998) for specimens from west Greenland deposits of the Albian Kome Formation., West Greenland.

Genus Klitzschophyllites Lejal-Nicol, 1987 emend. Gomez, Coiffard, Sender, MartínClosas, Villanueva-Amadoz \& Ferrer (2009)

\section{Klitzschophyllites choffatii}

(Saporta) Teixeira, 1948

emend. Gomez, Coiffard, Sender, Martín-

Closas, Villanueva-Amadoz \& Ferrer (2009)

Layers $\mathrm{B}$ to $\mathrm{D}$

(Fig. 9A, B)

SPECIMENS. - MPZ 2010/1057 to MPZ 2010/1129.

\section{DESCRIPTION}

Leaves simple and small, semicircular to ovoidal in shape, up to $2 \mathrm{~cm}$ long and $1.5 \mathrm{~cm}$ wide. They are bilateral symmetrical and petiolate. Petiole straight and robust ( $4 \mathrm{~mm}$ wide) preserved in some specimens. Leaf margin dentate with up to 15 teeth. Primary venation flabellate. Secondary veins straight, running from the primary veins. Tertiary veins alternate percurrent. Intramarginal vein present. Numerous primary veins diverging from the upper part of petiole and ending apically in the sinuses between teeth. Secondary veins ending in the tooth apex. Teeth retroflexed/retroflexed, apex mucronate. Tooth sinus glandular, bearing a circular gland.

\section{REMARKS}

The genus is based on material from Portugal (Teixeira 1948). Later it was suggested that the Tunisian (Barale \& Ouaja 2001) and Brazilian material (Mohr \& Rydin 2002; Mohr et al. 2006) was conspecific with material from Portugal. More recently Gomez et al. (2009) emended the genus with new material recovered from a fossil site in northeastern Spain (nearby the Estercuel plant fossil site) extending the temporal distribution of genus up to the Upper Albian. Nevertheless, Friis et al. (2010) indicate that figured specimens of Klitzschophyllites in the publications cited here-above are differents from the original description and drawings of the type species Protorrhipis choffatii erected by Saporta (1894). This authors suggest that the portuguese material is related to the aquatic fern Ceratopteris Brong.

\section{PALYNOLOGY}

The five samples from the uppermost part of the Utrillas Formation yielded rich and well-preserved palynological assemblages. Taxa identified are summarized in Table 1 (Figs 10; 11). The presence of Concavisporites punctatus and Converrucosisporites platyverrucosus that are not known to extend above the Albian-Cenomanian boundary, Afropollis jardinus, distributed from the middle Albian to Cenomanian and Stellatopollis barghoornii from the middle Albian to middle Cenomanian, together with Senectotetradites varireticulatus, which is restricted to the latest Albian-Cenomanian interval in Laurasia indicates a Late Albian age (Figs 10; 11).

The assemblage shows high diversity of palynomorphs, and particularly great abundance of gymnosperm pollen (mainly represented by Taxodiaceaepollenites hiatus, Araucariacites australis and Classopollis spp., followed in abundance 


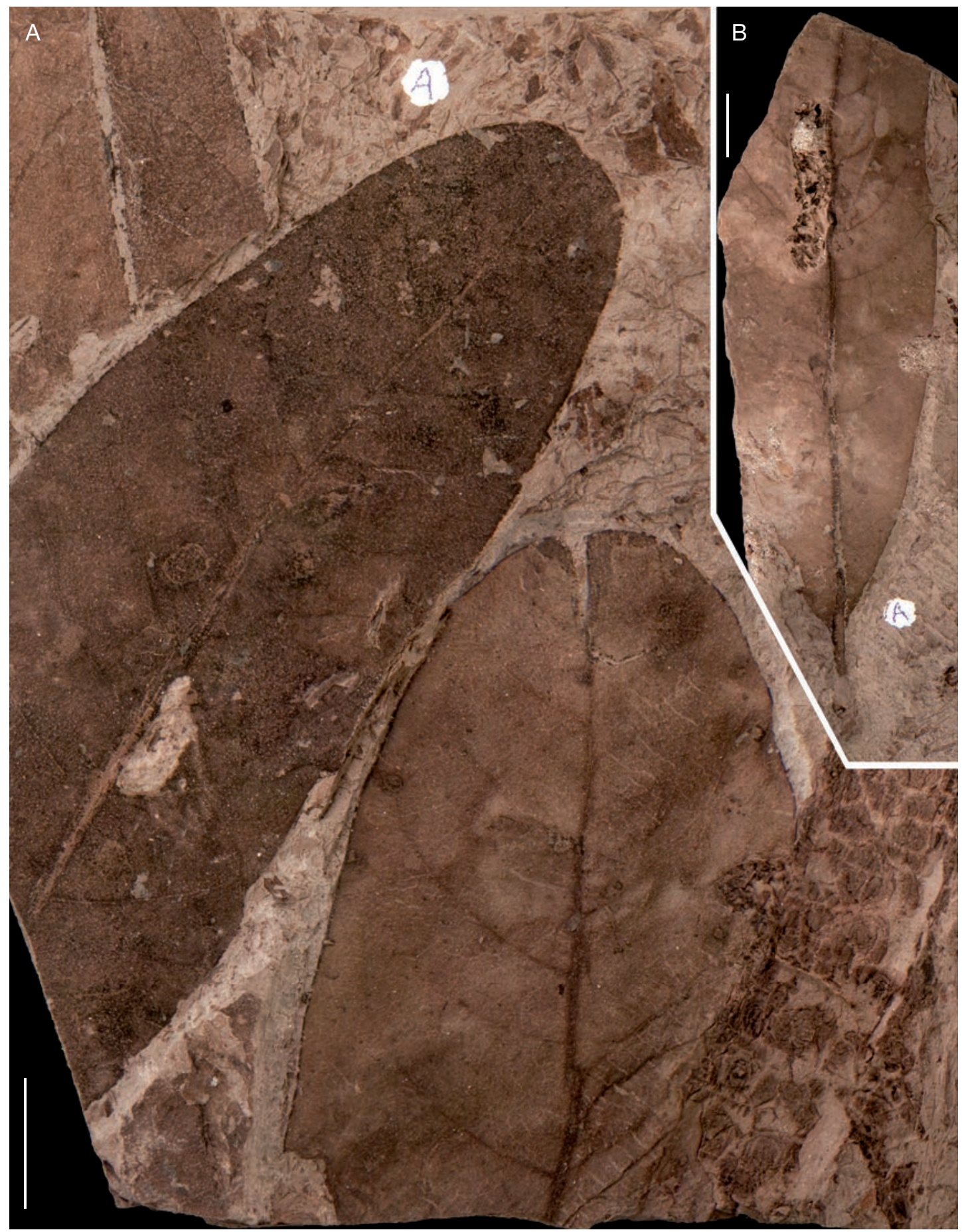

FIG. 8 - Angiosperms leaves: A, apical fragments of leaves of Angiosperms type 1; B, Angiosperm type 2 leaf with petiole. Scale bars: $1 \mathrm{~cm}$. 
TABLE 1. - List of palynomorphs from Estercuel fossil plant site (Teruel province, Spain). *, reworked palynomorphs.

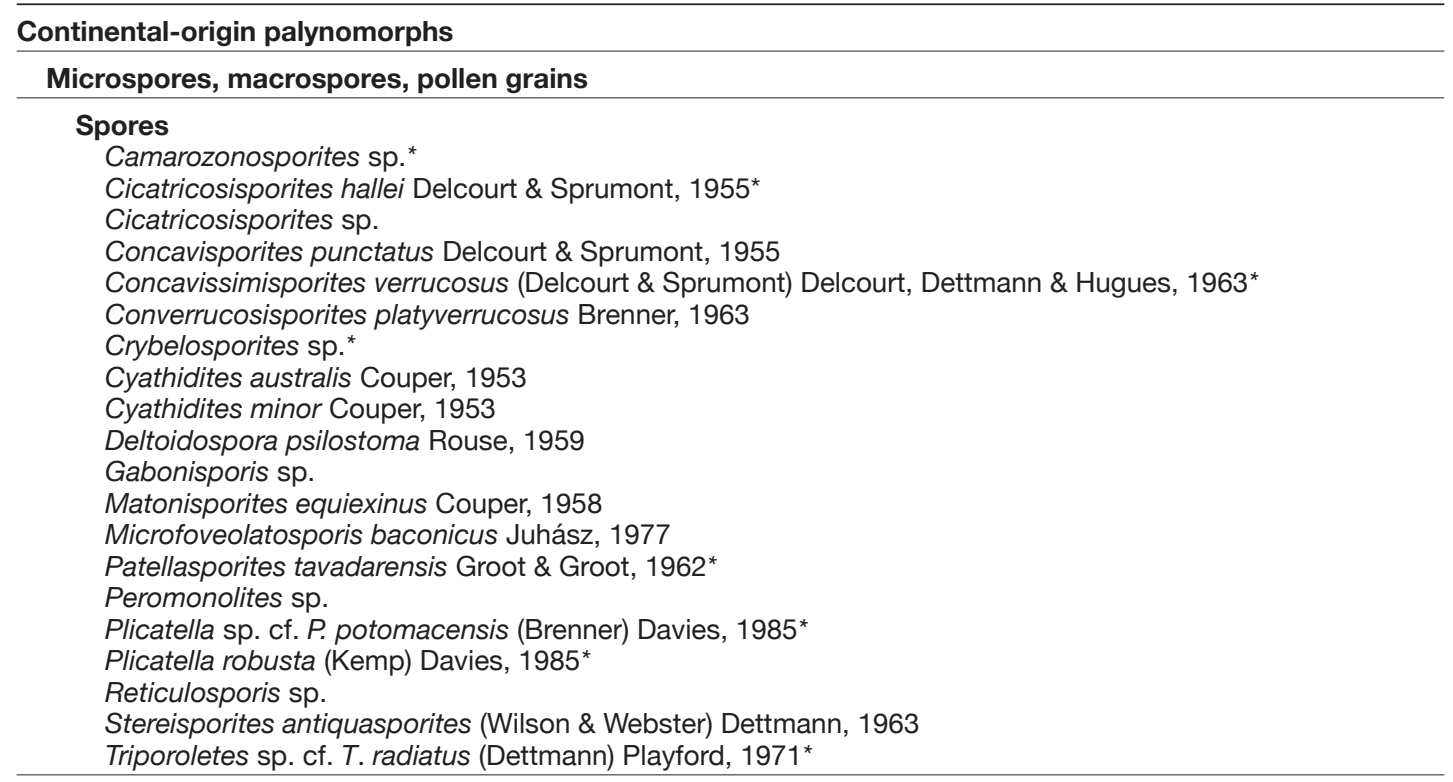

\section{Gymnosperm pollen}

Araucariacites australis (Cookson) Couper, 1953

Balmeiopsis limbata (Balme) Archangelsky, 1977

Cedripites canadensis Pocock, 1962

Classopollis major Groot \& Groot, 1962

Classopollis sp.

Cycadopites sp.

Ephedripites sp. cf. E. dudarensis Deák, 1964

Ephedripites sp. cf. E. multicostatus Brenner, 1963

Eucomiidites troedsonii (Erdtman) Potonié, 1958

Exesipollenites scabrosus Norris, 1969

Perinopollenites halonatus Phillips \& Felix, 1971

Singhia sp.

Spheripollenites sp.

Taxodiaceaepollenites hiatus (Potonié) Kremp, 1949

\section{Angiosperm pollen}

Afropollis jardinus Doyle, Jardiné \& Doerenkamp, 1982

Clavatipollenites hughesii Couper, 1958

Clavatipollenites minutus Brenner, 1963

Clavatipollenites tenellis Phillips \& Felix, 1971

Clavatipollenites sp.

Dichastopollenites sp. cf. D. reticulatus May, 1975

Liliacidites doylei Ward, 1986

Monosulcites chaloneri Brenner, 1963

Penetetrapites mollis Hedlund \& Norris, 1968

Pennipollis sp. cf. P. reticulatus (Brenner) Friis, Pedersen \& Crane, 2000

Pennipollis escuchensis Villanueva-Amadoz, Pons, Diez, Ferrer \& Sender, 2010

Pennipollis sp.

Phimopollenites augathellaensis (Burger) Dettmann, 1973

Retimonocolpites textus (Norris) Singh, 1983

Rousea sp.

Senectotetradites varireticulatus Dettmann, 1973

Stellatopollis barghoornii Doyle, 1975 
TABLE 1. - Continuation.

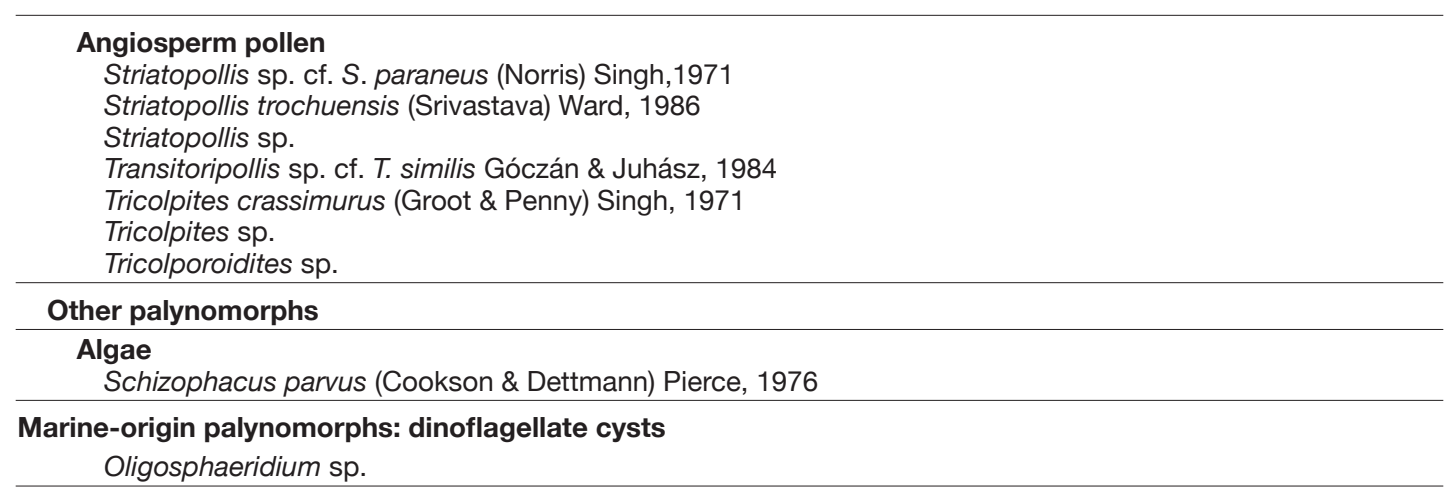

by Perinopollenites halonatus, Spheripollenites sp., Ephedripites spp., Exesipollenites scabrosus, Balmeiopsis limbata, Cycadopites spp., Cedripites canadensis, Eucommidites troedsonii and Singhia sp.) and, to a lesser extent, angiosperm pollen grains and spores. Spores are scarce, mainly represented by Cyathidites spp., Gabonisporis sp., Matonisporites equiexinus and Peromonolites sp., and in very low percentages Cicatricosisporites sp., Concavisporites punctatus, Converrucosisporites platyverrucosus, Deltoidospora psilostoma, Microfoveolatosporis baconicus and Stereisporites antiquasporites. The angiosperm assemblage consists of relative high percentage of Clavatipollenites spp. and Afropollis jardinus while other monoaperturate types such as Stellatopollis barghoornii, Dichastopollenites spp., Liliacidites doylei, Monosulcites chaloneri, Pennipollis spp., Retimonocolpites textus and Transitoripollis sp. cf. T. similis are less abundant. Tricolpates, mainly Tricolpites spp. followed by Phimopollenites augathellaensis, Rousea spp., Senectotetradites varireticulatus and Striatopollis spp., and multiporates, Penetetrapites mollis, are also less abundant. The first appearance of tricolporate pollen grains (Tricolporoidites sp.) is in the "Boundary Marls", but they are presented in a scarce number. The earliest evidence of this morphological type in northeastern Spain is suggested to be coincident in age with that of subzone II-C of the Potomac Group (Doyle \& Robbins 1977) in the Atlantic Coastal Plain (USA).

\section{DISCUSSION}

\section{BIOSTRATIGRAPHY}

The earliest tricolporates appeared in different areas at the Albian-Cenomanian transition. The stratigraphic levels showing the first occurrence of tricolporates in the latest Albian are: 1) Canada: below the Fish-Scale Marker in Shaftesbury Formation, Peace River area (Singh 1975); and 2) USA: Denton Shale Member of the Bokchito Formation, southern Oklahoma and northern Texas (Wingate 1980); near the base of Huntsman Shale and in the uppermost beds of the Dakota Sandstone, Denver basin, Colorado (Pannella 1966). Moreover, the first occurrence in Cenomanian stratigraphic levels are: 1) Canada: Dunvegan Formation, Alberta (Singh 1983); and 2) USA: Dakota Sandstone, northeastern Arizona (Agasie 1969); Red Branch Member of the Woodbine Formation, Oklahoma (Hedlund 1966); Raritan fire clay of the Raritan Formation, New Jersey (Groot et al. 1961); lower part of the Raritan Formation, Delaware (Brenner 1967), and near the top of the Patapsco Formation (beds at Elk Neck), Maryland (Doyle 1969).

The gondwanan influences are also evident from the palynological assemblage with the presence of high proportions of Afropollis jardinus, together with tethyan Stellatopollis barghoornii and some ephedralean pollen grains (Ephedripites spp. and Singhia sp.). Such taxa present a peak of abundance in the uppermost Albian-lowermost Cenoma- 


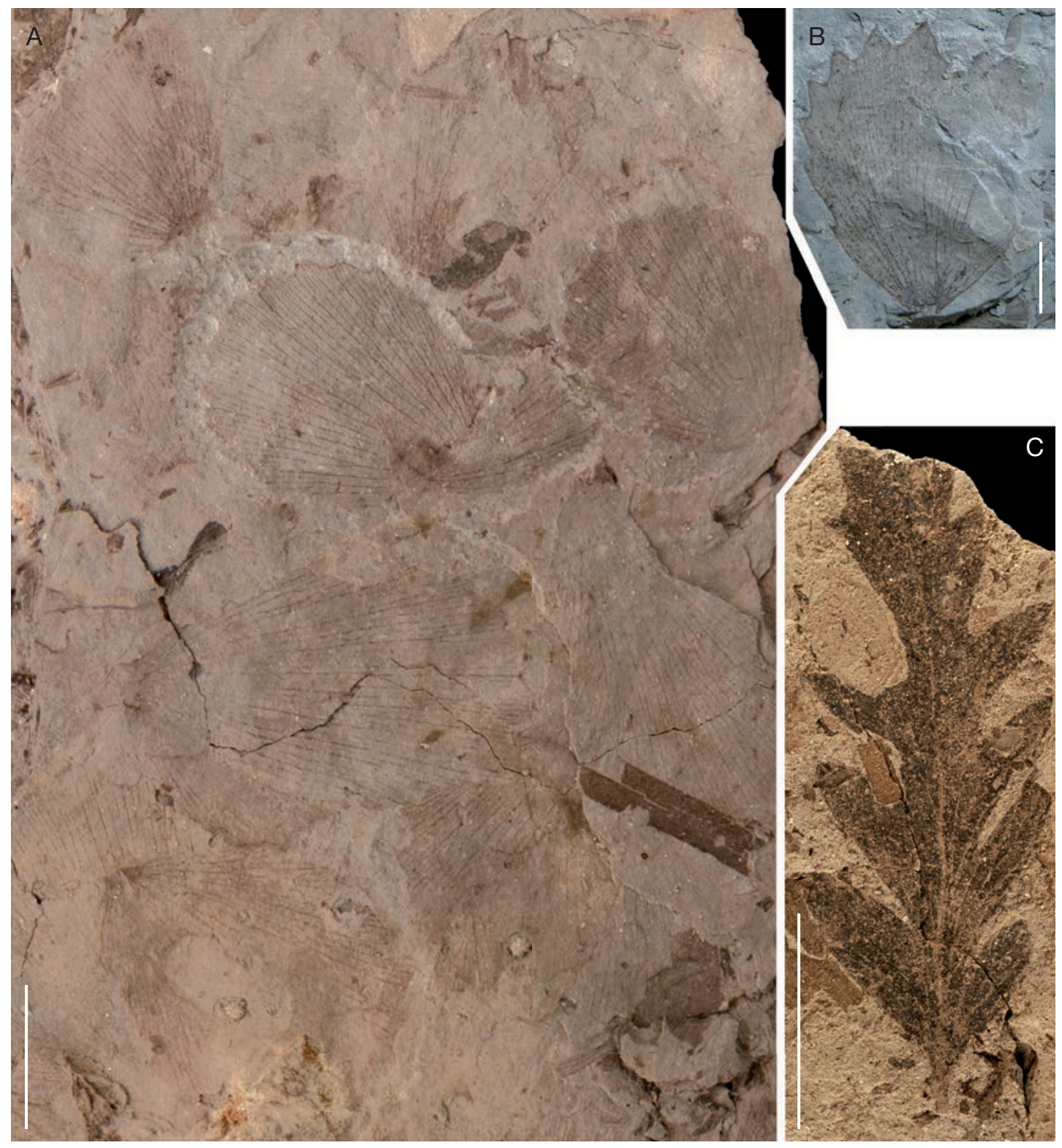

FIG. 9 - A, accumulation of Klitzschophyllites choffatii young leaves with poorly developed teeth; B, nearly complete leaf of Klitzschophyllites choffatii showing well-developed teeth; C, pinnately lobed leaf of Myricompia sp. Scale bars: $1 \mathrm{~cm}$.

nian deposits of the Iberian Plate as discussed in Villanueva-Amadoz et al. 2011.

The majority macrofossils of the Estercuel site are known to have a large distribution in the continental deposits of Late Albian-Early Cenomanian age. Nevertheless, it is the first time that the unique aquatic angiosperm Aquatifolia is recorded outside of the Dakota Formation deposits from the midwest of North America (United States), where it was first described by Wang \& Dilcher (2006a). Besides, 
A
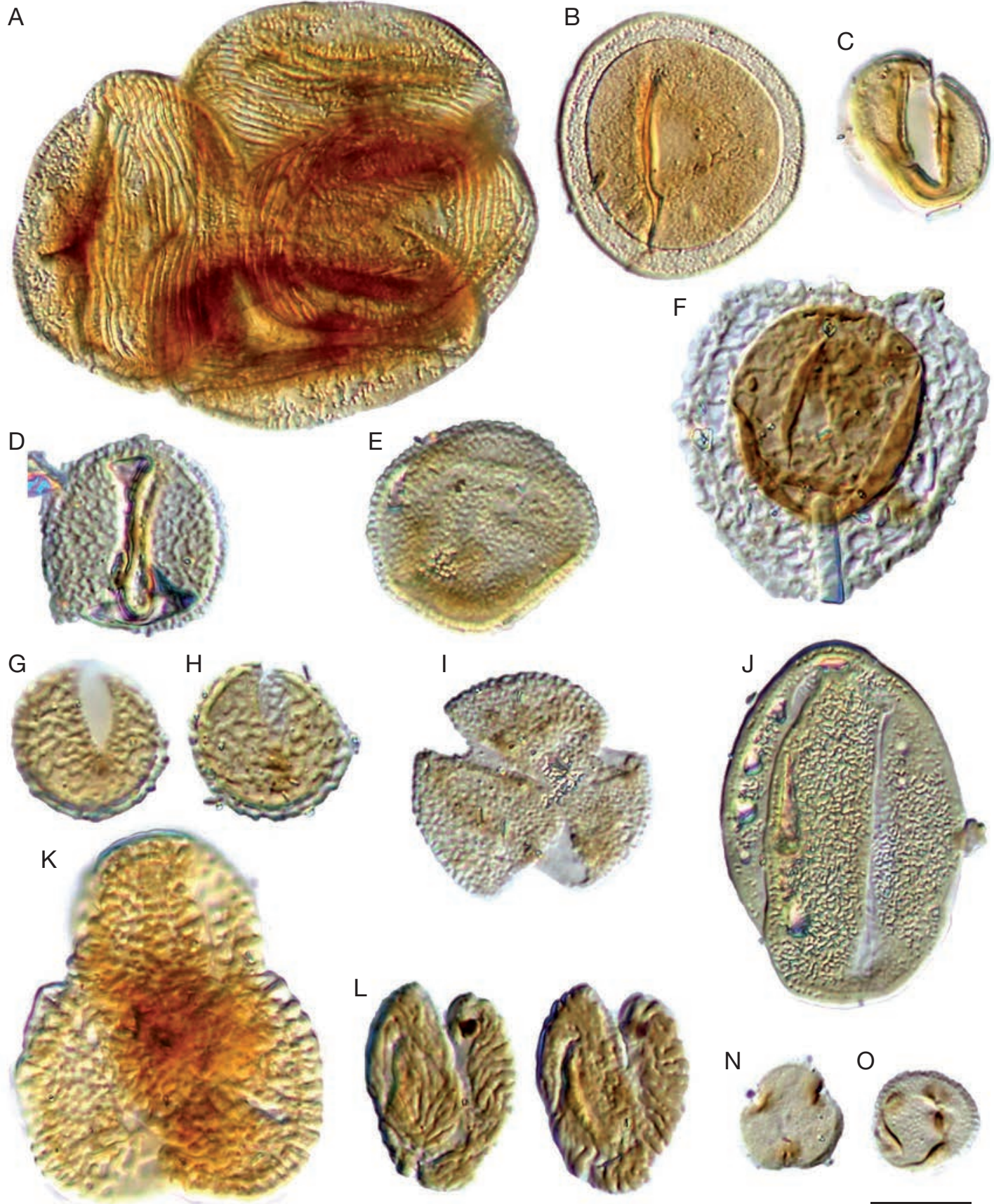

FIG. 10. - Photographs of some selected sporomorphs from the Estercuel section (Teruel province, northeastern Spain): A, Classopollis major; B, Perinopollenites halonatus, mid focus; C, Transitoripollis sp. cf. T. similis, distal face; D, Retimonocolpites textus, distal face; E, Clavatipollenites sp., mid focus; F, Afropollis jardinus, mid focus; G, H, Pennipollis sp. cf. P. reticulatus in distal (G) and proximal (H) faces; I, Rousea sp., polar view; J, Phimopollenites augathellaensis, equatorial view; K. Senectotetradites varireticulatus, equatorial view; L, M, Striatopollis sp., equatorial view; L, high focus; $\mathbf{M}$, same specimen, low focus; N, O, Tricolporoidites sp.; N, polar view; $\mathbf{O}$, equatorial view. Scale bar: $10 \mu \mathrm{m}$. Full taxa names are given in Table 1. 
the genus Myricompia observed in the present work has only been recovered from the sediments of the Upper Albian Kome Formation from west Greenland (Boyd 1998). The aquatic Klitzschophyllites with gondwanan affinities (see references in the systematic palaeobotany part) is well represented within the Estercuel site floral assemblages.

\section{TAPHONOMY, PALAEOECOLOGY}

\section{AND PALAEOENVIRONMENTS}

The rich plant bearing beds of the Estercuel fossil site include a number of different lithologies with a wide variety of floristic elements. The macrofloras occurring in the silty claystones and in the lower level corresponding to the laminated claystones (layers A to D) are very similar despite the different lithology. They consist mostly of semi-complete leaves of angiosperms type 1, a small number of leaves of angiosperms type 2 and Myricompia, abundant ramified shoots of the conifers Pagiophyllum, detached Podozamites leaves, long fragments of Desmiophyllum leaves, occasional pinnae of the fern Onychiopsis, centimeter to decimeter long moulds of stems and trunks and a massive concentration of fragments of plants of irregular shape as well as comminuted plant debris (Fig. 3). They are composed of milimeter to centimeter-sized remains of leaves, fragments of conifer axis and scales of conifers female cones, fragments of angiosperm leaves and occasionally fragments of charcoalified wood, some of them with angular shape. The lithologies and characteristics preservation of the plant remains may be related to deposition in a nearshore fluvial environment.

The main difference between the lower and the upper stratigraphical levels is based on the accumulations of Klitzschophyllites choffatti leaves, remains of Aquatifolia cf. fluitans and Isoetites sp. corresponding to the finest grained lithologies (laminated claystones of layers B, C and D) related to quiet water environments, possibly small ponds.

The flora of the upper level of dark laminated and bioturbated claystones (layer E) consists of numerous large ramified shoots of Pagiophyllum, leaves of Podozamites, fragments of strapped leaves of the gymnosperm Desmiophyllum and leaves of angiosperms type 1 and the presence of Cladophlebis type fern. All plant remains at this stratigraphical level are preserved as stained impressions with a coaly thin layer present, and the shoots of Pagiophyllum are always coalified. These characteristics might indicate the deposit of plants in a swampy environment.

It is noteworthy that a great number of terrestrial angiosperm leaves and a number of aquatic leaves, ocurring in all layers, are affected by galls, mines, circular holes and other structures indicating several kinds of insect-plant interactions (Figs 6A, B; 7A; 8C; 9A).

According to the palynological analysis, the algae Schizophacus parvus, nowadays indicating stagnant, shallow, and more or less mesotrophic freshwater habitats (Van Geel \& Van der Hammen 1978), would be associated to nearby freshwater environment. This suggestion is corroborated by the presence of Gabonisporis sp. (Marsileaceae) and Peromonolites sp. (Isoetaceae). These palynomorphs would reflect the composition of the local flora surrounding the subaquatic depositional environments.

Highly abundant gymnosperm pollen such as Araucariacites australis is interpreted as allochtonous representatives of a relatively nearby upland vegetation, whereas pollen of Taxodiaceaepollenites hiatus and Ephedripites probably represents nearby lowland coastal environments. These taxa were possibly transported to the depositional area as wind-borne particles as for extant representatives. Cheirolepidiaceous pollen was probably also wind dispersed (Srivastava 1976), however, the good preservation and the presence of tetrads of Classopollis major (Fig. 10A) indicate short transport. The latter taxon has also been interpreted as being produced by xeromorphic coastal plants, adapted to halophytic and riparian habitats from brackish marshes and fluvio-lacustrine freshwater environments (Watson 1977; Upchurch \& Doyle 1981; Alvin 1982; Pons \& Koeniguer 1985; Watson 1988; Gomez et al. 2002).

Among angiosperm pollen, Clavatipollenites appears to be abundant and well preserved indicating short transport, possibly by wind. These pollen grains have compared to Ascarina of the Chlorantaceae (Walker \& Walker 1984), which is wind-pollinated. 


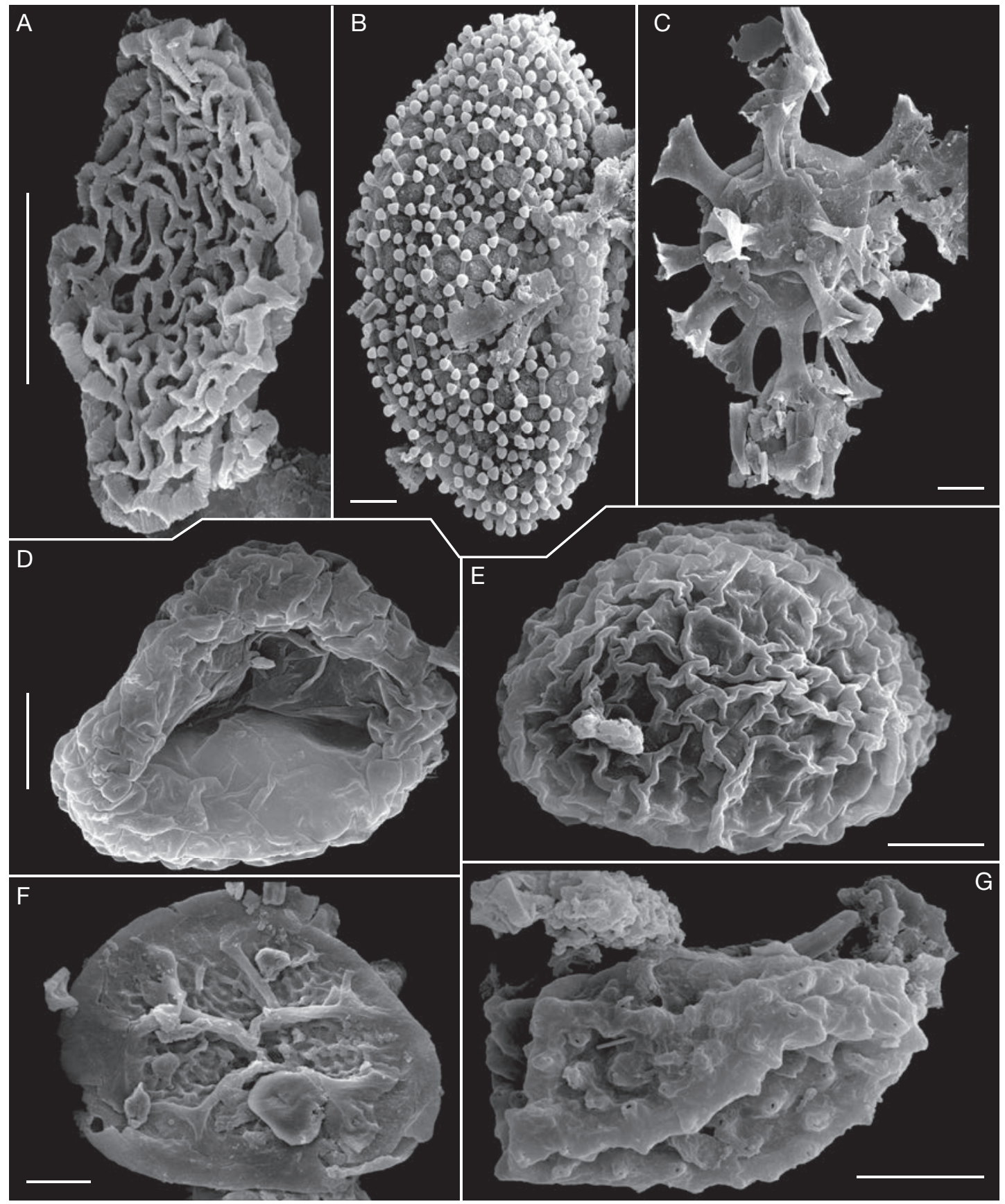

FIG. 11 - SEM images of sporomorphs from the Estercuel section (Teruel province, northeastern Spain): A, Afropollis jardinus; B, Stellatopollis barghoornii, lateral face; C, dinoflagellate cyst Oligosphaeridium sp.; D, Gabonisporites sp., proximal face; E, Gabonisporites sp., distal face; F, reworked Triporoletes sp. cf. T. radiatus, proximal face showing damage in the exine; G, Peromonolites sp., distal face. Scale bars: $10 \mu \mathrm{m}$. Full taxa names are given in Table 1. 
There are few well-preserved dinoflagellate cysts (Oligosphaeridium sp.) indicating a marine influence. However, their low abundance would indicate relative proximity to a coastal floodplain environment.

In addition, there are some reworked elements that appear eroded and with a higher thermal degree of organic maturation within the assemblage such as the spores Camarozonosporites sp., Cibotiumspora juncta, Cicatricosisporites spp., Concavissimisporites verrucosus, Patellasporites tavadarensis and Plicatella spp., together with the freshwater elements Crybelosporites sp. (related to Marsileaceous ferns) and Triporoletes sp. cf. T. radiatus (related to bryophytes). From this, it can be inferred that reworking and redepositing of older pollen and spores occurred because of fluvial influence.

According to the fossil fauna from Estercuel locality, moulds of mytilid bivalves (order Mytiloida, family Mytilidae) (Dr. Graciela Delvene, pers. comm.) up to $2 \mathrm{~cm}$ long and $1 \mathrm{~cm}$ wide in the finest grained lithology are noteworthy. At this fossil site the bivalves are usually preserved with the two valves still articulated (in connection) indicating little or no transport prior to deposition. The presence of this group of marine and brackish-water bivalves together with dinoflagellate cysts indicate some marine input into the depositional environment where the fossil plants were deposited.

\section{CONCLUSIONS}

The rich fossil floras recently discovered from the "Boundary Marls" unit of the Utrillas Formation at the Estercuel site, Teruel province, northeastern Spain, include diverse assemblages of green algae, aquatic lycopsids, pteridophytes, gymnosperms as well as terrestrial and aquatic angiosperms. The fossils include both allochthonous and parautochthonous elements deposited in swampy and fluvial sedimentary environments with tidally influence. The palynological data indicate a latest Albian age. The plant assemblage of the Estercuel site shows a mixture of Laurasian and Gondwanan floristical elements in the uppermost Albian deposits from northeastern Spain.

\section{Acknowledgements}

We thank the government of Aragón region for permissions and fieldwork grants. This article is a contribution to projects CGL2008-00809 and CGL2005-01121/BTE of the Ministerio de Ciencia e Innovación of the Spanish government. The authors thank SAMCA mining company for allowing us access to the plant fossil site and for their support and provision for excavation works. LMS, UVA and JF received economic support from project OTRI 2007-116 in collaboration with Paleoymás sociedad limitada. UVA received a fellowship award funded by the government of Navarra region. We thank Dr. Zarela Herrera of the Servicio de Fotografía Paleontológica. The authors thank Peter Crane, Valéry Malécot and an anonymous reviewer for critical reading, comments and suggestions to improve the manuscript. We also thank Mrs Cristóbal Rubio, Javier Gimeno and students of Mining Engineering and Marine Biology from Vigo University for their support and assistance in the fieldworks.

\section{REFERENCES}

AGASIE J. M. 1969. — Late Cretaceous palynomorphs from northeastern Arizona. Micropalaeontology 15: 13-30.

Aguilar M. J., Ramírez del Pozo J. \& Riba O. 1971. Algunas precisiones sobre la sedimentación y paleoecología del Cretácico inferior en la zona de UtrillasVillarroya de los Pinares, Teruel. Estudios Geológicos 27 (6): 497-512.

ALVIN K. L. 1982. — Cheirolepidiaceae: biology, structure and paleoecology. Review of Palaeobotany and Palynology 37: 71-98.

Barale G. \& Ouaja M. 2001. — Découverte de nouvelles flores avec des restes à affinités angiospermiennes dans le Crétacé inférieur du sud Tunisien. Cretaceous Research 22: 131-143.

BELL W. A. 1956. - Lower Cretaceous floras of western Canada. Geological Survey of Canada, Memoir 285, $331 \mathrm{p}$.

Bercovici A., Hadley A. \& Villanueva-Amadoz U. 2009. - Improving depth of field resolution for palynological microphotography. Palaeontologia Electronica 12 (2): 1-12.

Berry E. W. 1922. - The flora of the Cheyenne Sandstone of Kansas. U.S. Geological Survey Professional Paper 129: 199-225. 
BoyD A. 1998. - Cuticular and impressional angiosperm leaf remains from the Early Cretaceous of West Greenland. Palaeontographica 247 B: 1-53.

BRENNER G. J. 1967. — Early angiosperm pollen differentiation in the Albian to Cenomanian deposits of Delaware (U.S.A.). Review of Palaeobotany and Palynology 1: 219-227.

CAlonge A. 1989. - Bioestratigrafia del Cenomaniense de la Cordillera Ibérica por Foraminiferos bentónicos. Unpublished doctoral thesis. Universidad Complutense, Madrid, $535 \mathrm{p}$.

CANÉROT J. 1974. - Recherches géologiques aux confins des chaînes ibérique et catalane. ENADIMSA series, $\mathrm{n}^{\circ}$ 4, Madrid, $517 \mathrm{p}$.

Coiffard C., Gomez B. \& Thévenard F. 2007. — Early Cretaceous angiosperm invasion of western Europe and major environmental changes. Annals of Botany 100 (3): 545-553.

DOYLE J. A. 1969. - Cretaceous angiosperm pollen of the Atlantic Coastal Plain and its evolutionary significance. Journal of Arnold Arboretum 50 (1): 1-35.

Doyle J. A. \& Robbins N. I. 1977. — Angiosperm pollen zonation of the continental Cretaceous of the Atlantic Coastal Plain and its application to deep wells in the Salisbury embayment. Palynology 1: 43-78.

ERDTMAN G. 1943. - An Introduction to Pollen Analysis. Chronica Botanica Company, Waltgam, Massachussets, $238 \mathrm{p}$.

Gandolfo M. A. \& Cúneo R. N. 2005. - Fossil Nelumbonaceae from the La Colonia Formation (Campanian-Maastrichtian, Upper Cretaceous), Chubut, Patagonia, Argentina. Review of Palaeobotany and Palynology 133: 169-178.

Fris E. M., Pedersen K. R. \& Crane P. R. 2010. Cretaceous diversification of angiosperms in the western part of the Iberian Peninsula. Review of Palaeobotany and Palynology 162: 341-361.

Gomez B., Martín-Closas C., Barale G., Solé de Porta N., Thévenard F. \& Guignard G. 2002. Frenelopsis (Coniferales: Cheirolepidiaceae) and related male organ genera from the Lower Cretaceous of Spain. Palaeontology 45 (5): 997-1036.

Gomez B., Daviero-Gomez V., Perrichot V., Thévenard F., Coiffard C., Philippe M. \& Néraudeau D. 2004. - Assemblages floristiques de l'AlbienCénomanien de Charente-Maritime (SO France). Annales de Paléontologie 90: 147-159.

Gomez B., Coiffard C., Sender L. M., MartínClosas C., Villanueva-Amadoz U. \& Ferrer J. 2009. - Klitzschophyllites, aquatic basal Eudicots (Ranunculales?) from the Upper Albian (Lower Cretaceous) of north-eastern Spain. International Journal of Plant Sciences 170 (8): 1075-1085.

Groot J. J., Penny J. S. \& Groot C. R. 1961. — Plant microfossils and age of the Raritan, Tuscaloosa and Magothy Formations of the eastern United States.
Palaeontographica 108 B: 121-140.

Hadley A. 2006. - CombineZM and CZBatch - Free image stacking software for depth of field correction. Available from: http://www.hadleyweb.pwp. blueyonder.co.uk

Hayes V., Schneider E. L. \& Carlquist S. 2000. Current perspective on basal angiosperms. International Journal of Plant Sciences, supplement 161 (6): 183-191.

HEDLUND R. W. 1966. - Palynology of the Red Branch Member of the Woodbine Formation (Cenomanian), Bryan County, Oklahoma. Oklahoma Geological Survey bulletin 112: 1-69.

Hickey L. J. \& DoYLE J. A. 1977. — Early Cretaceous evidence for angiosperm evolution. Botanical Review 43 (1): 3-104.

Lendínez A., Ruíz V. \& CARls P. 1989. - Memoria del Mapa Geológico de España a escala 1:5000, no 466 (Moyuela). Instituto Geológico y Minero de España. Madrid, 116 p.

LESQUEREUX L. 1883. - Contributions to the fossil flora of the western territories. Part 3. The Cretaceous and Tertiary floras. United States Geological Survey 8: 2-108.

LESQUEREUX L. 1892. - The flora of the Dakota Group. United States Geological Survey 17: 1-400.

LiDGARD S. \& CRANE P. R. 1988. - Quantitative analyses of the early angiosperm radiation. Nature 331: 344-346.

Miller R. E., WaTling J. R. \& Robinson S. A. 2009. Functional transition in the floral receptacle of the sacred lotus (Nelumbo nucifera): from thermogenesis to photosynthesis. Faculty of Science - Papers 23. University of Wollongwong, Australia. Available at: http://works.bepress.com/srobinson/23

MoHR B. A. R. \& RYDIN C. 2002. — Trifurcatia flabellata n. gen. n. sp., a putative monocotyledon angiosperm from the Lower Cretaceous Crato Formation (Brazil). Mitteilungen aus dem Museum für Naturkunde in Berlin, Geowissenschaftliche Reihe 5: 335-344.

Mohr B. A. R., Bernardes de Oliveira M. E. C., Barale G. \& OujJa M. 2006. - Palaeogeographic distribution and ecology of Klitzschophyllites, an Early Cretaceous angiosperm in southern Laurasia and northern Gondwana. Cretaceous Research 27: 464-472.

Neumann M. \& Schroeder R. (eds) 1985. — Les grands foraminifères du Crétacé moyen de la région méditerranénne. Géobios 18 (Supplément 1), 161 p.

Pannella G. 1966. - Palynology of the Dakota Group and Graneros Shale (Cretaceous) of the Denver Basin; Colorado. Unpublished doctoral thesis, University of Colorado, Boulder, United States, 170 p.

PARDO G. 1979. - Estratigrafía y sedimentología de las formaciones detríticas del Cretácico inferior terminal en el Bajo Aragón turolense. Unpublished Doctoral Thesis, Universidad de Zaragoza, Spain, 470 p.

Pons D. \& Koeniguer J.-C. 1985 - Les Gymnospermes. Clartés : l'Encyclopédie du Présent, éditions techniques, Paris, fasc. 4070, 20 p. 
Rushforth S. R. 1971. - A flora from the Dakota Sandstone Formation (Cenomanian) near Westwater, Grand County, Utah. Brigham Young University, Science Bulletin (Biological Series) 14 (3), 44 p.

SAMYLINA V. A. 1988. - [Akagalinsk stratoflora of northeastern Asia] Akagalinskaya stratoflora severo-vostoka Azii. Akademia Nauk SSSR, Botanicheski Institut V. L. Komarova, Leningrad, 132 p. (in Russian).

SAPORTA G. DE 1894. — Flore fossile du Portugal. Nouvelles contributions à la flore Mésozoïque accompagnées d'une notice stratigraphique par Paul Choffat. Imprimerie de l'Académie royale des Sciences, Lisbon, 228 p.

SCHWARZWALDER R. N. JR \& DilChER D. L. 1991. Systematic placement of the Platanaceae in the Hamamelidae. Annals of the Missouri Botanical Garden 78 (4): 962-969.

Sender L. M., Gomez B., Diez J. B., Coiffard C., Martín-Closas C., Villanueva-Amadoz U. \& FERRER J. 2010. — Ploufolia cerciforme gen. et comb. nov.: aquatic angiosperm leaves from the upper Albian of north-eastern Spain. Review of Palaeobotany and Palynology 161: 77-86.

SiNGH C. 1975. - Stratigraphic significance of early angiosperm pollen in the mid-Cretaceous of Alberta. Geological Association of Alberta, Special Paper 13: 365-389.

SingH C. 1983. - Cenomanian microfloras of the Peace river area, northwestern Alberta. Research Council of Alberta Bulletin 44: 1-322.

Skog J. E. \& Dilcher D. L. 1994. — Lower vascular plants of the Dakota Formation in Kansas and Nebraska. Review of Paleobotany and Palynology 80: 1-18.

SkOG J. E., Dilcher D. L. \& PotTer F. W. 1992. A new species of Isoetites from the mid-Cretaceous Dakota Group of Kansas and Nebraska. American Fern Journal 82: 151-161.

Skog J. E. \& Dilcher D. L. 1992. - A new species of Marsilea from the Dakota Formation in central Kansas. American Journal of Botany 79: 982-988.

SORIA A. R. 1997. - La sedimentación en las cuencas marginales del Surco Ibérico durante el Cretácico inferior y su control estructural. Unpublished doctoral thesis, University of Zaragoza, Spain, 363 p.

Sicer R. A. \& Herman A. B. 2001. - The AlbianCenomanian flora of the Kukpowruk River, western North Slope, Alaska: stratigraphy, palaeofloristics, and plant communities. Cretaceous Research 22: 1-40.

Spicer R. A., Ahlberg A., Herman A. B., Kelley S. P., RAIKEVICH M. I. \& ReES P. M. 2002. - Palaeoenvironment and ecology of the middle Cretaceous Grebenka flora of northeastern Asia. Palaeogeography, Palaeoclimatology, Palaeoecology 184: 65-105.

SRIVASTAVA S. K. 1976. - The fossil pollen genus Classopollis. Lethaia 9: 437-457.

TeIXeIra C. 1948. - Flora Mesozóica Portuguesa. Part I. Serviços Geológicos de Portugal, Lisbon, 118 p.
UpChurch G. R. Jr \& Doyle J. A. 1981. — Paleoecology of the conifers Frenelopsis and Pseudofrenelopsis (Cheirolepidiaceae) from the Cretaceous Potomac Group of Maryland and Virginia, in Romans R. C. (ed.), Geobotany II. Plenum Publishing Corps, New York: 167-202.

Upchurch G. R. JR \& Dilcher D. L. 1990. — Cenomanian angiosperm leaf megafossils, Dakota Formation, Rose Creek I locality, Jefferson County, southeastern Nebraska. United States Geological Survey Bulletin 1915: 1-55.

Upchurch G. R. JR. \& Wolfe J. A. 1993. - Cretaceous vegetation of the Western Interior and adjacent regions of North America. Geological Association of Canada Special Paper 29: 243-281.

Upchurch G. R. JR, Crane P. R. \& Drinnan A. N. 1994. - The megaflora from the Quantico Locality (Upper Albian), Lower Cretaceous Potomac Group of Virginia. Virginia Museum of natural History Memoir $4,57 \mathrm{p}$.

VAKHRAMEEV V. A. 1952. - [Stratigraphy and Fossil Flora of Jurassic and Cretaceous Deposits of Vilyui Trough and Adjacent Part of Near Verkhoyansk Foredeep. Regionalnaya Stratígrajiya SSSR]. Volume 1. Moscow, Nauka, 340 p. (in Russian).

VAKHRAMEEV V. A. 1976. — Development of Cretaceous floras of northern part of Pacific Belt. Paleontologiya. Morskaya Geologiya. Moscow, Nauka, 128-137 (in Russian).

VAKHRAMEEV V. A. 1991. - Jurassic and Cretaceous Floras and Climates of the Earth. Cambridge University Press, Cambridge, New York, 318 p.

Van Geel B. \& Van der Hammen T. 1978. - Zygnemataceae in Quaternary Colombian sediments. Review of Paleobotany and Palynology 25: 377-392.

VillanueVa-Amadoz U. 2009. - Nuevas aportaciones palinoestratigráficas para el intervalo AlbienseCenomaniense en el Sector NE de la Península Ibérica. Implicaciones paleogeográficas y paleoclimáticas. Unpublished doctoral thesis, Universidad de Zaragoza, Spain, $632 \mathrm{p}$.

Villanueva-Amadoz U., Sender L. M., Diez J. B., Ferrer J. \& Pons D. 2011. - Palynological studies of the boundary marls unit (Albian-Cenomanian) from northeastern Spain. Paleophytogeographical implications. Geodiversitas 33 (1): 137-176. http:// dx.doi.org/10.5252/g2011n1a7

Villanueva-Amadoz U., Benedetti A., Diez J. B., Méndez J. \& Sender L. M. (2012). - Focused Ion Beam slicing and imaging: a new method in characterization of palaeopalynological remains. Grana 51: 1-9.

WALKER J. W. \& WALKeR A. G. 1984. — Ultrastructure of Lower Cretaceous angiosperm pollen and the origin and early evolution of flowering plants. Annals of the Missouri Botanical Garden 71 (2): 464-521. 
WANG H. 2002. — Diversity of angiosperm leaf megafossils from the Dakota Formation (Cenomanian, Cretaceous), North Western Interior, U.S.A. Unpublished doctoral thesis, University of Florida, Gainesville, 395 p.

Wang H. \& Dilcher D. L. 2006a. - Aquatic Angiosperms from the Dakota Formation (Albian, Lower Cretaceous), Hoisington III locality, Kansas, USA. International Journal of Plant Sciences 167 (2): 373-383.

WANG H. \& Dilcher D. L. 2006b. — Early Cretaceous angiosperm leaves from the Dakota Formation: Braun Ranch Locality, Kansas, USA. Palaeontographica 273 B: 101-137.
WANG X. 2008. - Mesofossils with Platanaceous affinity from the Dakota Formation (Cretaceous) in Kansas, USA. Palaeoworld 17 (3-4): 246-252.

WATSON J. 1977. - Some Lower Cretaceous conifers of the Cheirolepidiaceae from the USA and England. Palaeontology 20: 715-749.

WATSON J. 1988. - The Cheirolepidiaceae, in BECK C. B. (ed.), Origin and Evolution of Gymnosperms. Columbia University Press, New York: 382-447.

Wingate F. H. 1980. - Plant microfossils from the Denton Shale Member of the Bokchito Formation (Lower Cretaceous, Albian) in southern Oklahoma. Oklahoma Geological Survey Bulletin 130, 93 p.

Submitted on 16 April 2010; accepted on 17 February 2011. 
